\title{
The Glycosaminoglycans of Human Plasma
}

\author{
Alberto Calatroni, Patricia V. Donnelly, and Nicola Di Ferrante \\ From the Laboratories of Connective Tissue Research of the Department of \\ Biochemistry and the Division of Orthopedic Surgery, Department of Surgery, \\ Baylor University College of Medicine, Houston, Texas 77025
}

\begin{abstract}
A B S TRACT A method is proposed for the measurement of glycosaminoglycans (GAG) on $5-10 \mathrm{ml}$ of plasma. It is based on the adsorption of GAG on small ECTEOLA columns followed by measurement of the hexuronic acid in the $\mathrm{NaCl}$ eluates. Routine use of the method has indicated the presence of a GAG fraction that adsorbs readily on ECTEOLA ("free" GAG) and of another that adsorbs on it only after treatment with papain ("bound" GAG). "Free" and "bound" GAG have been measured in normal adults, normal children, and children affected by mucopolysaccharidosis type $I$; the results obtained are in good agreement with those previously reported in the literature.

Various analyses performed on purified "free" and "bound" GAG have confirmed that chondroitin-4sulfate is the main glycosaminoglycan of normal human plasma where it occurs both free and bound to protein and at various levels of sulfation. The presence of small amounts of heparan sulfate and keratan sulfate has also been demonstrated.
\end{abstract}

Metabolic experiments performed in rabbits have indicated that plasma GAG derive from peripheral tissues and increase sharply after papain injection. In young animals the "free" GAG have a faster turnover than the "bound," possibly a reflection of active processes of remodeling and calcification. The synthesis of the "free" and "bound" GAG, as measured with ${ }^{35} \mathrm{~S}$-sulfate incorporation, seems to proceed at the same rate, and the hypothesis has been advanced that as a result of the action of tissue proteases, part of the "bound" GAG may be transformed into "free" GAG, the latter being immediately extruded from the tissues into the circulatory system.

\section{INTRODUCTION}

The presence of glycosaminoglycans (GAG) $(1)^{1}$ in human plasma has been demonstrated in various labora-

Received for publication 15 August 1968.

1 The nomenclature suggested by Balazs and Jeanloz (1) has been used. tories. In 1955 Badin, Schubert, and Vouras (2) isolated material containing hexuronic acid and hexosamine in equimolar amounts from the "euglobulin" fraction of human plasma. With their procedure, the average values for normal individuals and for patients with active rheumatoid arthritis were found to be, respectively, 206 and $388 \mu \mathrm{g}$ of hexuronic acid/100 ml of plasma.

In the same year, Bassiouni (3) extracted from 420 $\mathrm{ml}$ of normal human blood a material which on paper electrophoresis could be separated into a component moving at the same rate as cartilage chondroitin sulfate and another with lower mobility.

In 1957 Bollet, Seraydarian, and Simpson (4), using a modification of Badin's method, studied 34 normal adults and obtained values ranging from 215 to $385 \mu \mathrm{g}$ of hexuronic acid/100 $\mathrm{ml}$ of plasma. No apparent differences were found between males and females or between individuals of different age. The material isolated had a hexosamine: hexuronic acid ratio of 1.3 (72\% galactosamine, $28 \%$ glucosamine) and could be separated by paper chromatography with various solvents into two components, both depolymerized by testicular hyaluronidase; one behaved like chondroitin sulfate and had a hexosamine: hexuronic acid ratio of 1.1 , whereas the other was not conclusively identified and had a hexosamine : hexuronic acid ratio of 1.5 .

Working with purified plasma protein fractions, Kerby (5) demonstrated in 1958 that plasma GAG are present only in Cohn fractions III and IV-1, where they seem to be bound to the protein rather than to the lipid components of the fractions. After tryptic digestion and precipitation with cetyltrimethyl ammonium bromide, the GAG could be separated by paper chromatography into two fractions, corresponding to those described by Bollet et al. (4).

Isolation and purification of GAG from human plasma or "euglobulin" fraction provided Schiller (6) with material that could be separated electrophoretically into two fractions. The faster moving one was identified as chondroitin-4-sulfate on the basis of analytical data, infrared pattern, specific rotation, and sensitivity to testic- 
ular hyaluronidase. The slower moving one (containing $\mathrm{N}$, hexosamine, hexuronic acid, and ester sulfate in 1.00 , $0.99,0.71,0.54$ ratio) was scarcely sensitive to testicular hyaluronidase and remained unidentified. A concentration of $310-440 \mu \mathrm{g}$ of hexuronic acid/100 $\mathrm{ml}$ of normal human plasma was found in this study.

Quite recently, the method of Bollet et al. (4) was employed by Friman and Brunish (7) to isolate plasma GAG that were subsequently analyzed by electrophoresis on cellulose acetate strips. The major component, representing $44-100 \%$ of the total GAG, was found to behave like chondroitin sulfate; occasionally slower components, with the mobility of hyaluronic acid or with intermediate mobilities, were also found. The results, although essentially qualitative, indicated that a great variability of plasma GAG may exist among different individuals.

The present study has been undertaken for the following reasons :

(1) to devise a simple method which could be of value in routine clinical determination of plasma GAG.

(2) to investigate the nature of the association between GAG and plasma proteins. In the method of Badin et al. (2), tryptic digestion of the "euglobulin" fraction was emphasized as a preliminary step to the precipitation of GAG. In the method of Bollet, however, the "euglobulin" fraction was treated for $30 \mathrm{~min}$ with $0.4 \mathrm{M}$ perchloric acid at room $t^{\circ}$, a treatment that could hardly break covalent bonds between protein and GAG. Nevertheless, the values obtained in the two laboratories are quite compatible, a fact that seems to indicate either that plasma GAG are not linked covalently to proteins or that the protein moiety does not affect the solubility of the complex in perchloric acid.

(3) to attempt separation and identification of the various fractions of plasma GAG which have been demonstrated with various techniques in different laboratories. To this extent, we have used for measurement of plasma GAG a modification of a method independently described by Wessler (8) and by one of us (9) for the measurement of urinary GAG.

\section{METHODS}

Blood samples were obtained from medical students and laboratory personnel who were free from acute illness and without history of chronic disease. Blood samples from patients with mucopolysaccharidosis type I (10) and from young, mentally retarded patients were obtained through the kindness of Dr. Buford Nichols, Department of Pediatrics, Baylor University College of Medicine, and Dr. Gordon Farrell, Texas Research Institute of Mental Sciences.

Measurement of plasma GAG. The technique used for duplicate measurement consists of the following steps:

(a) $20 \mathrm{ml}$ of blood is added to $0.20 \mathrm{ml}$ of aqueous EDTA solution (EDTA, tetrasodium salt, $7.98 \mathrm{~g}$, EDTA, $2.05 \mathrm{~g} /$ $100 \mathrm{ml}$; final $\mathrm{pH} 7.10$ ). After mixing, plasma is obtained by centrifugation. Four $0.7 \times 2 \mathrm{~cm}$ columns of ECTEOLA ${ }^{2}$

${ }^{2}$ ECTEOLA cellulose, the reaction product of cellulose with epichlorohydrin and triethanolamine, can be obtained in the $\mathrm{OH}^{-}$form (8) are prepared as described (see Standardization of ECTEOLA and preparation of columns, below) and labeled Nos. 1-4.

(b) Two equal aliquots of each plasma sample $(5 \mathrm{ml}$ each or less) are passed through columns 1 and 2 at a flow rate of $5 \mathrm{ml} / \mathrm{hr}$. Each column is washed with $15 \mathrm{ml}$ of $0.9 \%$ $\mathrm{NaCl}$ and then closed to prevent dryness. The effluent from each column (plasma plus washing) is collected in a $25 \mathrm{ml}$ Erlenmeyer flask, to which cysteine $\mathrm{HCl} 0.5 \mathrm{M}$ and EDTA solution $(0.20 \mathrm{ml}$ each $)$ are added. The $\mathrm{pH}$ is adjusted to $6.20-6.40$ with $2.5 \mathrm{~N}$ acetic acid, and $2 \mathrm{mg}$ of twice crystallized papain ${ }^{3}$ are added to each flask before incubation at $56^{\circ} \mathrm{C}$ overnight.

(c) The content of each flask is centrifuged for $15 \mathrm{~min}$ at $8000 \times g$, and the supernatants are applied to columns 3 and 4 at a flow rate which allows complete drainage in about $1 \mathrm{hr}$. Each sediment remaining after centrifugation is washed once with $3-\mathrm{ml}$ of $0.9 \% \mathrm{NaCl}$, twice with $1.5 \mathrm{ml}$ of $1.0 \mathrm{M}$ $\mathrm{NaCl}$, and eventually with $5 \mathrm{ml}$ of $0.9 \% \mathrm{NaCl}$. The washings from each sediment are pooled, diluted to final $0.15 \mathrm{M} \mathrm{NaCl}$ concentration $(0.9 \% \mathrm{NaCl})$, and applied to the respective column. The four ECTEOLA columns are then washed with $100-\mathrm{ml}$ of $0.9 \% \mathrm{NaCl}$, at a flow rate of $40-50 \mathrm{ml} / \mathrm{hr}$, and the flow is stopped as soon as the top layer of the cellulose becomes exposed.

(d) For the elution, $3 \mathrm{ml}$ of $2.0 \mathrm{M} \mathrm{NaCl}$ is delivered onto each column, and the effluent is collected into calibrated Shevky-Stafford tubes in two approximately equal fractions. The borate-carbazole reaction is performed in duplicate on aliquots from each tube, using an aqueous solution of glucuronolactone as a standard. As previously stated (9), despite the high salt concentration of the eluting solution, no depression of color formation was observed. The values obtained are expressed as $\mu \mathrm{g}$ of hexuronic acid/10 ml of plasma (Tables I and II). Whereas in normal individuals all the plasma GAG are found in the first $2.0 \mathrm{M} \mathrm{NaCl}$ fraction, in patients with high levels of plasma GAG the second fraction is also positive.

Standardization of ECTEOLA and preparation of columns. ECTEOLA "standard type" was used. A lot with a stated capacity of $0.40 \mathrm{meq} / \mathrm{g}$ is desirable because it allows the use of short columns which require small volumes of eluant. However, since it is difficult to obtain ECTEOLA of such high capacity, it is necessary to standardize the type available in order to establish the smallest volume compatible with a complete retention of the GAG present in the plasma sample.

Two methods of standardization have been used. 200-300 $\mu \mathrm{g}$ of chondroitin sulfate in $0.9 \% \mathrm{NaCl}$ are passed through a column of known dimensions, according to the procedure described under $(b)$. The amount of material which is not retained on the column and appears in the washings or the amount which is retained on the column and is eluted with $2.0 \mathrm{M} \mathrm{NaCl}$ is measured with the borate-carbazole reaction. Alternatively, 5-ml of plasma digested with papain are passed through a column of known dimensions, following the procedure described under $(c)$. The effluent and column washings are passed through a second column of identical dimensions. Upon elution of the columns, the presence or absence of hexuronic acid-containing material in the eluate of the second column indicates whether or not the retention of the first column was adequate and if its dimensions could be further reduced.

from Schleicher and Schuell Co., Keene, N. H., or Brown Paper Co., Berlin, N. H.

${ }^{3}$ Papain $\times 2$ crystalline, Nutritional Biochemicals Corp., Cleveland, Ohio. 
New ECTEOLA is initially washed with $1 \mathrm{~N} \mathrm{HCl}$ and distilled water. Before use it is washed with $1 \mathrm{~N} \mathrm{NaOH}$ and distilled water, and suspended in $0.9 \% \mathrm{NaCl}$. Used ECTEOLA is regenerated with $1 \times \mathrm{NaOH}$ but it should be standardized periodically to insure against loss of retentive capacity. The ECTEOLA suspension is poured into columns consisting of a $15 \mathrm{ml}$ centrifuge tube sealed to a $10 \mathrm{~cm}$ long Pyrex tube having an internal diameter of $7-\mathrm{mm}$ (Fig. 1). The end of the tube is fitted in the large opening of a Teflon Multifit connector ${ }^{4}$ which contains a porous polyethylene disc for support of the cellulose and a lower opening which accommodates a $5 \mathrm{~cm}$ length of polyethylene tubing, ${ }^{\mathrm{s}} 1.0-\mathrm{mm}$ internal diameter. The column flow is regulated by means of a screw compressor clamp applied to the polyethylene tubing.

Recovery tests. Recovery tests were performed by applying to $0.7 \times 2 \mathrm{~cm}$ ECTEOLA columns $200 \mu \mathrm{g}$ of chondroitin-4-sulfate, $200 \mu \mathrm{g}$ of chondroitin-4-sulfate, and 200 $\mathrm{mg}$ of crystalline bovine albumin, or a papain digest of $200 \mu \mathrm{g}$ of chondroitin-4-sulfate and $200 \mathrm{mg}$ of crystalline bovine albumin. The papain digestion was performed as specified under $(b)$ and $(c)$. The columns were washed and eluted as described under $(d)$, and the recoveries were calculated in terms of hexuronic acid (Table IV).

Isolation and identification of $G A G$. Isolation was achieved by a large scale modification of the method described. Duplicate 634-ml aliquots of pooled plasma (containing $50 \mu \mathrm{g}$ of total $\mathrm{GAG}$, as hexuronic acid $/ 10 \mathrm{ml}^{6}$ ) were applied to $2 \times 15 \mathrm{~cm}$ columns of ECTEOLA in the $\mathrm{OH}^{-}$ form (columns $\mathrm{P} 1$ and $\mathrm{P} 2$ ), which were washed with $0.9 \%$ $\mathrm{NaCl}$ until the absorbance at $278 \mathrm{~m} \mu$ was negative. The columns were then eluted with $4.0 \mathrm{M} \mathrm{NaCl}$, and the hexuronic acid-positive peaks from the two columns were combined, desalted, and concentrated by ultrafiltration through a UM-1 Diaflo membrane," and eventually lyophilized. Redissolved in a small volume of water, the material was passed through several $2 \times 14 \mathrm{~cm}$ columns of SE Sephadex C-50 medium (11), equilibrated, and eluted with a $\mathrm{pH} 4.0$ citratephosphate buffer, $0.0062 \mathrm{M}$. The ratio between absorption at $278 \mathrm{~m} \mu$ and hexuronic acid content of the effluent from each column was measured, and the GAG were considered to be free of contaminating protein when such a ratio could not be reduced further. At this point, electrophoresis on acetate cellulose strips $(0.05 \mathrm{M}$ borate buffer, $\mathrm{pH} 7.6,150 \mathrm{v}$ for 30 min at room temperature) indicated two rapidly migrating, poorly resolved areas which could be stained with Alcian blue $\left(0.05 \%\right.$ in $\left.0.2 \mathrm{M} \mathrm{MgCl}_{2}\right)$ and absence of material which would stain with Thiazine red $(0.1 \%$ in $1 \%$ acetic acid). The material thus obtained, referred to as "free GAG" (see Discussion), was used for the identification procedures.

The effluents and washes from columns $\mathrm{P} 1$ and $\mathrm{P} 2$, adjusted to $\mathrm{pH} 6.2-6.4$, were separately digested with $1.5 \mathrm{~g}$ of crude, activated papain (12) for $68 \mathrm{hr}$ at $56^{\circ} \mathrm{C}$. The digests were

"Multifit Teflon connector No. $3020-3 / 8$ " to $B$, or the entire column is available from Glass Engineering Co., Inc., Houston, Texas.

${ }^{5}$ PX039 Polyethylene, Becton, Dickinson and Co., Rutherford, N. J.

- The amounts of GAG found in blood bank plasma are consistently higher than those found in freshly drawn blood. These higher values might be due either to destruction of white cells, with liberation of GAG (3), or to variation of the level of circulating GAG in relation to food intake (4). Our subjects were bled either in mid-morning or midafternoon and were not fasting, whereas the blood donors were fasting and were bled in the early morning.

${ }^{7}$ Amicon Corp., Lexington, Mass.

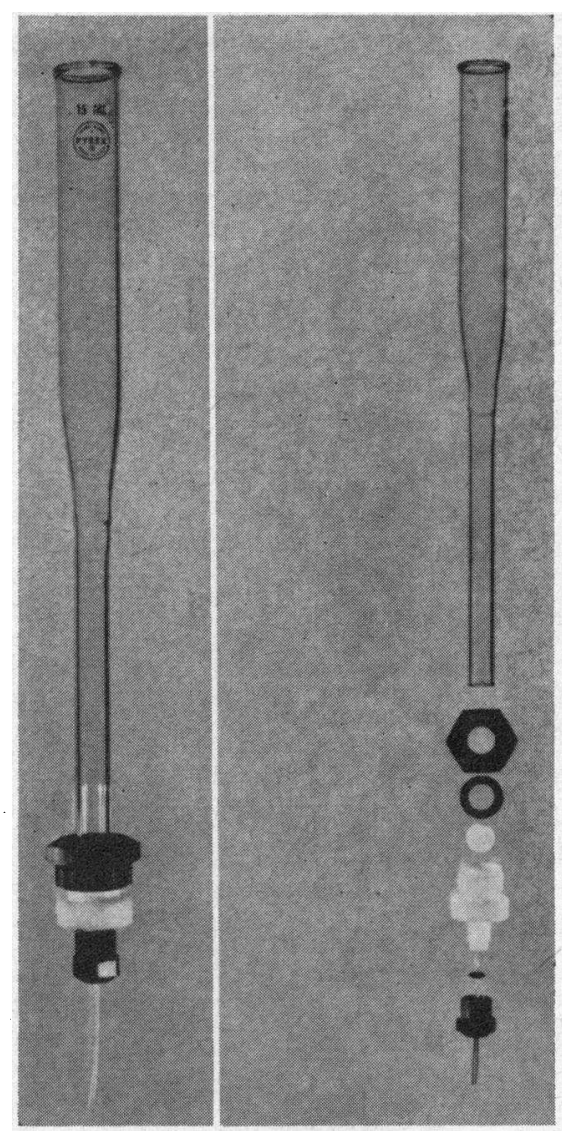

FIGURE 1 Details of the column used for chromatography of plasma GAG on ECTEOLA. The internal diameter of the cylindrical part of the glass tube is $0.7 \mathrm{~mm}$.

cleared by centrifugation at $8000 \mathrm{~g}$, and the residues were washed and extracted with $1.0 \mathrm{M} \mathrm{NaCl}$ as described under (c). The two digests and their diluted washings were passed through $2 \times 15 \mathrm{~cm}$ ECTEOLA columns (columns P3 and P4), were washed, and eluted as described for columns P1 and P2; the hexuronic acid-positive peaks from the two columns were combined, desalted, concentrated by ultrafiltration, and lyophilized. Electrophoresis on acetate cellulose strips demonstrated two fast-migrating, well-separated A1cian blue-positive areas and a slow-moving, Thiazine redstainable area. The material thus obtained, referred to as "bound GAG" (see Discussion), was used for the identification procedures.

The total amount of "free GAG" (1210 $\mu \mathrm{g}$ of hexuronic acid) was divided into two equal aliquots, and one of them was incubated with $100 \mu \mathrm{g}$ (30 USP U) of bovine testicular hyaluronidase for $20 \mathrm{hr}$ at $37^{\circ} \mathrm{C}$ in $0.1 \mathrm{M}$ acetate buffer, $\mathrm{pH}$ 4.85, $0.1 \mathrm{M}$ in $\mathrm{NaCl}$. Thereafter, the digested and nondigested aliquots were each applied to a $0.9 \times 3 \mathrm{~cm}$ column of Dowex $1 \times 2,200-400 \mathrm{mesh}, \mathrm{Cl}^{-}$form, and each column was eluted with increasing concentrations of $\mathrm{NaCl}$ (13). Elution with a given concentration of $\mathrm{NaCl}$ was continued as long as hexuronic acid-containing material was eluted from the column. The recovery of hexuronic acid from the two columns was quantitative, and the patterns of elution obtained are illustrated in Fig. 2. Each pattern of elution was divided 
TABLE 1

Plasma GAG of Normal Adults, Expressed as $\mu \mathrm{g}$ of Hexuronic Acid/10 ml of Plasma*

\begin{tabular}{|c|c|c|c|c|}
\hline & Age & Free & Bound & Total \\
\hline \multicolumn{5}{|l|}{ Normal males } \\
\hline 1 C. A. & 25 & 4.4 & 16.4 & 20.8 \\
\hline 2 B. H. & 23 & 5.8 & 28.3 & 34.1 \\
\hline 3 G. C. & 33 & 4.2 & 9.1 & 13.3 \\
\hline 4 J. E. C. & 23 & 3.8 & 12.9 & 16.7 \\
\hline 5 C. K. & 23 & 3.6 & 7.6 & 11.2 \\
\hline 6 R. E. N. & 24 & 6.3 & 17.2 & 23.5 \\
\hline 7 R. B. & 25 & 4.9 & 10.1 & 15.0 \\
\hline 8 S. R. A. & 22 & 6.7 & 27.0 & 33.7 \\
\hline 9 T. M. B. & 24 & 6.3 & 22.7 & 29.0 \\
\hline 10 R. O. & 23 & 5.5 & 32.8 & 38.3 \\
\hline 11 P. K. N. & 23 & 5.3 & 46.6 & 51.9 \\
\hline $12 \mathrm{~J} . \mathrm{K}$. & 23 & 6.6 & 32.5 & 39.1 \\
\hline 13 G. J. L. & 22 & 8.9 & 32.0 & 40.9 \\
\hline 14 D. P. & 24 & 9.6 & 34.5 & 44.1 \\
\hline $15 \mathrm{~T} . \mathrm{W}$. & 25 & 9.0 & 36.8 & 45.8 \\
\hline 16 L. M. $\ddagger$ & 33 & 5.9 & 14.8 & 20.7 \\
\hline Mean \pm SD & & $6.05 \pm 1.82$ & $23.8 \pm 11.61$ & $29.8 \pm 12.85$ \\
\hline \multicolumn{5}{|l|}{ Normal females } \\
\hline 1 P. D. & 34 & 7.0 & 10.0 & 17.0 \\
\hline 2 M. B. & 26 & 6.0 & 9.3 & 15.3 \\
\hline $3 \mathrm{H.S}$. & 28 & 4.5 & 15.1 & 19.6 \\
\hline 4 L. C. & 27 & 2.4 & 15.4 & 17.8 \\
\hline 5 W. B. & 26 & 5.0 & 18.7 & 23.7 \\
\hline 6 D.P. & 21 & 9.7 & 16.0 & 25.7 \\
\hline 7 T. G. & 22 & 5.0 & 25.6 & 30.6 \\
\hline 8 B. D. & 19 & 5.3 & 23.0 & 28.3 \\
\hline 9 S. T. & 22 & 5.3 & 32.2 & 37.5 \\
\hline 10 B. M. & 23 & 4.5 & 5.3 & 9.8 \\
\hline $11 \mathrm{~J} . \mathrm{M}$. & 42 & 7.5 & 31.5 & 39.0 \\
\hline $12 \mathrm{~J} . \mathrm{B}$. & 33 & 7.2 & 9.4 & 16.6 \\
\hline $13 \mathrm{~J} . \mathrm{H}$. & 24 & 4.5 & 17.6 & 22.1 \\
\hline $14 \mathrm{~S} . \mathrm{S}$. & 22 & 7.4 & 12.8 & 20.2 \\
\hline 15 P. K. & 23 & 5.9 & 26.5 & 32.4 \\
\hline $16 \mathrm{~J} . \mathrm{L}$. & 23 & 5.7 & 19.8 & 25.5 \\
\hline 17 L. S. & 21 & 5.8 & 19.8 & 25.6 \\
\hline 18 F.M..$\S$ & 20 & 10.0 & 19.2 & 29.2 \\
\hline \multirow[t]{2}{*}{19 F. B. $7 \S$} & 19 & 9.4 & 31.0 & 40.4 \\
\hline & & 6.9 & 19.0 & 25.9 \\
\hline \multirow{2}{*}{20 S. F. $\neq \S$} & 17 & 8.2 & 29.0 & 37.2 \\
\hline & & 5.3 & 24.6 & 29.9 \\
\hline \multirow[t]{2}{*}{21 C. W. $+\S$} & 19 & 4.6 & 13.2 & 17.8 \\
\hline & & 5.4 & 11.5 & 16.9 \\
\hline 22 A. F. $\ddagger$ & 26 & 8.3 & 21.3 & 29.6 \\
\hline Mean \pm SD & & $6.27 \pm 1.86$ & $19.07 \pm 7.50$ & $25.34 \pm 8.14$ \\
\hline
\end{tabular}

* Each value represents the mean of duplicate determinations.

$\ddagger$ Mentally retarded but without known metabolic defect.

Repetitive measurements were performed on different days or weeks. 
into several peaks (Fig. 2), and each peak was desalted, lyophilized, and assayed for its hexuronic acid content.

The total amount of "bound GAG" ( $5176 \mu \mathrm{g}$ hexuronic acid) was dissolved in $10 \mathrm{ml}$ of distilled water. 1-ml aliquot was incubated with $100 \mu \mathrm{g}$ of testicular hyaluronidase under the conditions described. Thereafter, the digest and another equivalent, nondigested sample were fractionated on Dowex $1 \times 2$ columns as described for the "free GAG." The recoveries were quantitative, and the patterns of elution, as well as the division into various peaks, are illustrated in Fig. 3.

The material present in each peak was used for the following analytical procedures: (1) hexuronic acid, performed with the carbazole method of Dische (14), the borate modification of Bitter and Muir (15), and the naphthoresorcinol method of Pelzer and Staib (16); (2) total amino sugars and glucosamine: galactosamine ratio performed after hydrolysis in $4 \mathrm{~N} \mathrm{HCl}$ for $8 \mathrm{hr}$ at $100^{\circ} \mathrm{C}$ with the Technicon amino acid analyzer, using a $0.6 \times 30$ $\mathrm{cm}$ cation exchange column and the ninhydrin reagent; (3) 2-deoxy-2-sulfoaminohexose, with the indole reaction of Dische and Borenfreund (17), performed after hydrolysis and deamination with nitrous acid for $80 \mathrm{~min}$, according to Lagunoff and Warren (18). The possible presence of 2-deoxy-2-aminohexose was assessed by performing acetylation of the material before hydrolysis with nitrous acid; (4) neutral sugar, measured with the anthrone method (19);

(5) total sulfur, measured according to a modification of

TABLE II

Plasma GAG of Normal Children and Patients with Mucopolysaccharidosis Type I, Expressed as $\mu \mathrm{g}$ of Hexuronic Acid $/ 10 \mathrm{ml}$ of Plasma*

\begin{tabular}{|c|c|c|c|c|}
\hline & Age & Free & Bound & Total \\
\hline \multicolumn{5}{|c|}{ Normal children } \\
\hline Males & & & & \\
\hline N. A. & 8 & 8.0 & 34.5 & 42.5 \\
\hline \multirow[t]{2}{*}{ S. L.f } & 14 & 8.6 & 30.5 & 39.1 \\
\hline & & 9.7 & 29.5 & 39.2 \\
\hline G. W. & 8 & 7.3 & 29.3 & 36.6 \\
\hline Mean \pm SD & & $8.40 \pm 1.02$ & $30.95 \pm 2.42$ & $39.35 \pm 2.42$ \\
\hline \multicolumn{5}{|l|}{ Females } \\
\hline \multirow[t]{2}{*}{ K. L.f } & 7 & 13.6 & 23.5 & 37.1 \\
\hline & & 10.9 & 39.5 & 50.4 \\
\hline F. A. & 8 & 9.5 & 24.1 & 33.6 \\
\hline G. V.' & 14 & 12.4 & 35.4 & 47.8 \\
\hline \multirow[t]{2}{*}{ Mean \pm SD } & & $11.60 \pm 1.78$ & $30.62 \pm 8.06$ & $42.22 \pm 8.14$ \\
\hline & \multicolumn{3}{|c|}{ Patients with mucopolysaccharidosis type I } & \\
\hline \multicolumn{5}{|l|}{ Males } \\
\hline T. C. & 7 months & 23.0 & 38.2 & 61.2 \\
\hline \multirow{2}{*}{ H. T. $\neq$} & 4 & 24.4 & 46.0 & 70.0 \\
\hline & & 23.3 & 38.0 & 61.3 \\
\hline \multirow[t]{7}{*}{ J.F.f } & 10 & 15.0 & 41.5 & 56.5 \\
\hline & & 13.6 & 62.4 & 76.0 \\
\hline & & 21.0 & 52.5 & 73.5 \\
\hline & & 29.5 & 71.0 & 100.5 \\
\hline & & 23.0 & 61.0 & 84.0 \\
\hline & & 23.5 & 61.1 & 89.6 \\
\hline & & 27.3 & 62.8 & 90.1 \\
\hline Mean \pm SD & & $22.32 \pm 4.87$ & $53.95 \pm 12.30$ & $76.27 \pm 14.55$ \\
\hline \multicolumn{5}{|l|}{ Females } \\
\hline \multirow[t]{2}{*}{ C. H. $\ddagger$} & 5 & 14.9 & 29.1 & 44.0 \\
\hline & & 12.7 & 29.8 & 42.5 \\
\hline \multirow[t]{3}{*}{ G. C. $\ddagger$} & 10 & 31.0 & 38.0 & 69.0 \\
\hline & & 27.0 & 49.0 & 76.0 \\
\hline & & 5.3 & 28.0 & 43.3 \\
\hline Mean \pm SD & & $18.18 \pm 10.59$ & $36.78 \pm 8.06$ & $54.96 \pm 16.21$ \\
\hline
\end{tabular}

* Each value represents the mean of duplicate determinations.

$\ddagger$ Repetitive measurements were performed on different days or weeks. 
TABLE III

Recovery of Chondroitin-4-Sulfate Applied to a $0.7 \times 2 \mathrm{~cm}$ ECTEOLA Column, OH- Form, Either Alone or with Bovine Albumin*

\begin{tabular}{ccc}
\hline $\begin{array}{c}\text { Chondroi- } \\
\text { tin-4- } \\
\text { sulfate }\end{array}$ & Crystalline bovine albumin & Recovery \\
\hline $\begin{array}{c}\mu g \\
\text { hexuronic } \\
\text { acid }\end{array}$ & $m g$ & $\%$ \\
47.40 & 0 & \\
47.40 & 0 & 105.0 \\
48.10 & 200 & 103.0 \\
51.60 & 200 & 99.2 \\
48.10 & $200+1 m g$ crystalline papain $\ddagger$ & 100.5 \\
48.10 & $200+1 m g$ crystalline papain \\
48.10 & $200+1 \mathrm{mg}$ crystalline papain $\ddagger$ & 98.0 \\
\hline
\end{tabular}

* The columns were washed and eluted as specified in Methods under $(d)$.

‡Incubation with papain was performed as described in Methods under $(b)$ and $(c)$.

the method of Antonopoulos (20); (6) infrared analysis performed with the Beckman IR-9 spectrophotometer, using $10-20 \mu \mathrm{g}$ of material dried on an Irtran $^{8}$ plate.

The results of the various analyses are presented in Tables V and VI.

Metabolic experiments. $500 \mu \mathrm{c}$ of carrier-free sodium sulfate- ${ }^{85} \mathrm{~S}$ in water were injected i.m. into two New Zealand white rabbits (Nos. 1 and 2, 6-8 wk old, 1.36 kg body wt) which were bled by cardiac puncture at various intervals after the injection. The injections of radioactive isotope were repeated 54 and $108 \mathrm{hr}$ after the first injection. $72 \mathrm{hr}$ after the last ${ }^{35} \mathrm{~S}$ injection, the rabbits were injected intravenously with $1 \mathrm{ml}$ of $1 \%$ crude papain in water (21), and they were bled $6,24,48$, and $72 \mathrm{hr}$ later. All the blood samples were processed for the measurement of plasma GAG with the method described, using $0.9 \% \mathrm{NaCl}$ containing $0.005 \mathrm{M} \mathrm{Na}_{2} \mathrm{SO}_{4}$ for the preparation and washing of the columns. The specific activity ( $\mathrm{cpm}{ }^{*} \mathrm{~S} / \mu \mathrm{g}$ hexuronic acid) of the "free" and "bound" GAG was measured as follows: duplicate $100 \mu \mathrm{l}$ aliquots of each eluate were added to $5-\mathrm{ml}$ of 2 -methoxyethanol and $10-\mathrm{ml}$ of toluene containing $15 \mathrm{~g}$ of 2,5-diphenyloxazole (POP) and $50 \mathrm{mg}$ of $1,4-$ bis-2-(5-phenyloxazolyl) benzene (POPOP)/liter. The radioactivity was measured in a Packard Tri-Carb Liquid Scintillation spectrometer, Model 3003. Corrections for decay of the isotope were made with appropriate standards, and absence of quenching was assessed with an external standard device. The results obtained are presented in Table VI. The same experiment was performed on two older rabbits (Nos. 3 and 4, 10-12 wk old, 1.7 and $2.1 \mathrm{~kg}$ body wt) using 250 $\mu c$ of carrier-free sodium sulfate- ${ }^{35} \mathrm{~S}$ for each injection. The results obtained are presented in Table VII.

\section{RESULTS}

Tables I and II present the values for plasma GAG (expressed as $\mu \mathrm{g}$ of hexuronic acid/10 ml of plasma) obtained from normal adults, normal children, and children affected by mucopolysaccharidosis type $I$.

\footnotetext{
${ }^{8}$ Beckman Instruments, Inc., S. Pasadena, Calif.
}

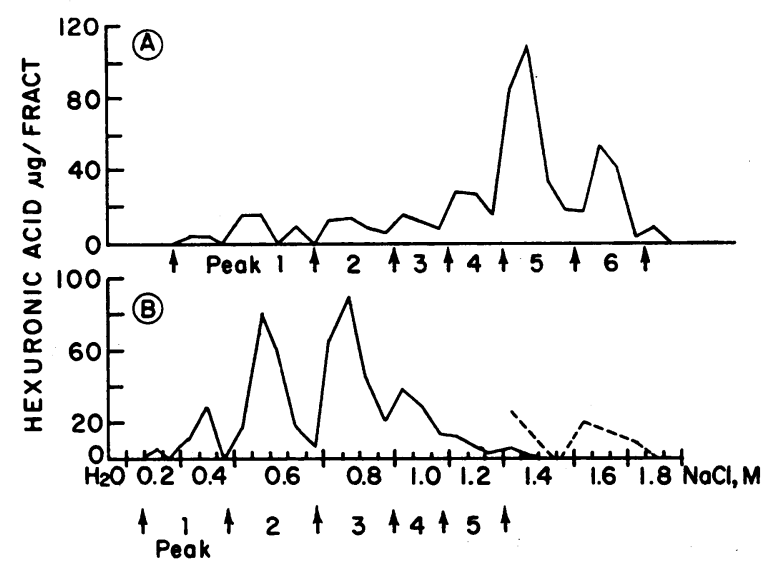

FIGURE 2 Fractionation of "free" plasma GAG on Dowex $1 \times 2$ columns. (A) Before treatment with hyaluronidase; recovery $98.5 \%$. (B) After treatment with hyaluronidase; recovery $97.1 \%$. $(\longrightarrow)=$ hexuronic acid; $(---)=$ galactose.

The results of the recovery tests (Table III) indicate that chondroitin-4-sulfate is quantitatively retained on, and eluted from, ECTEOLA columns independently from the presence of the enzyme papain, bovine albumin, or its products of proteolytic digestion. The fractionation of the "free" and "bound" GAG on Dowex $1 \times 2$, before and after incubation with testicular hyaluronidase, is illustrated in Figs. 2 and 3. It is evident that the "free" GAG are resolved into a more complicate fractionation pattern than the "bound" GAG and that the

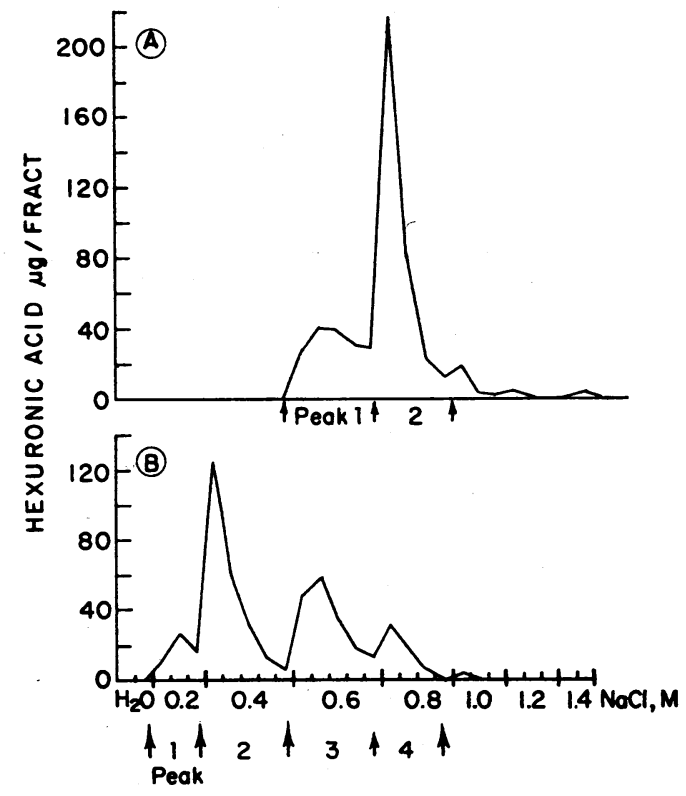

FIgURE 3 Fractionation of "bound" plasma GAG on Dowex $1 \times 2$ columns. (A) Before hyaluronidase treatment; recovery $100 \%$. (B) After hyaluronidase treatment; recovery $101 \%$. ( ) $=$ hexuronic acid. 


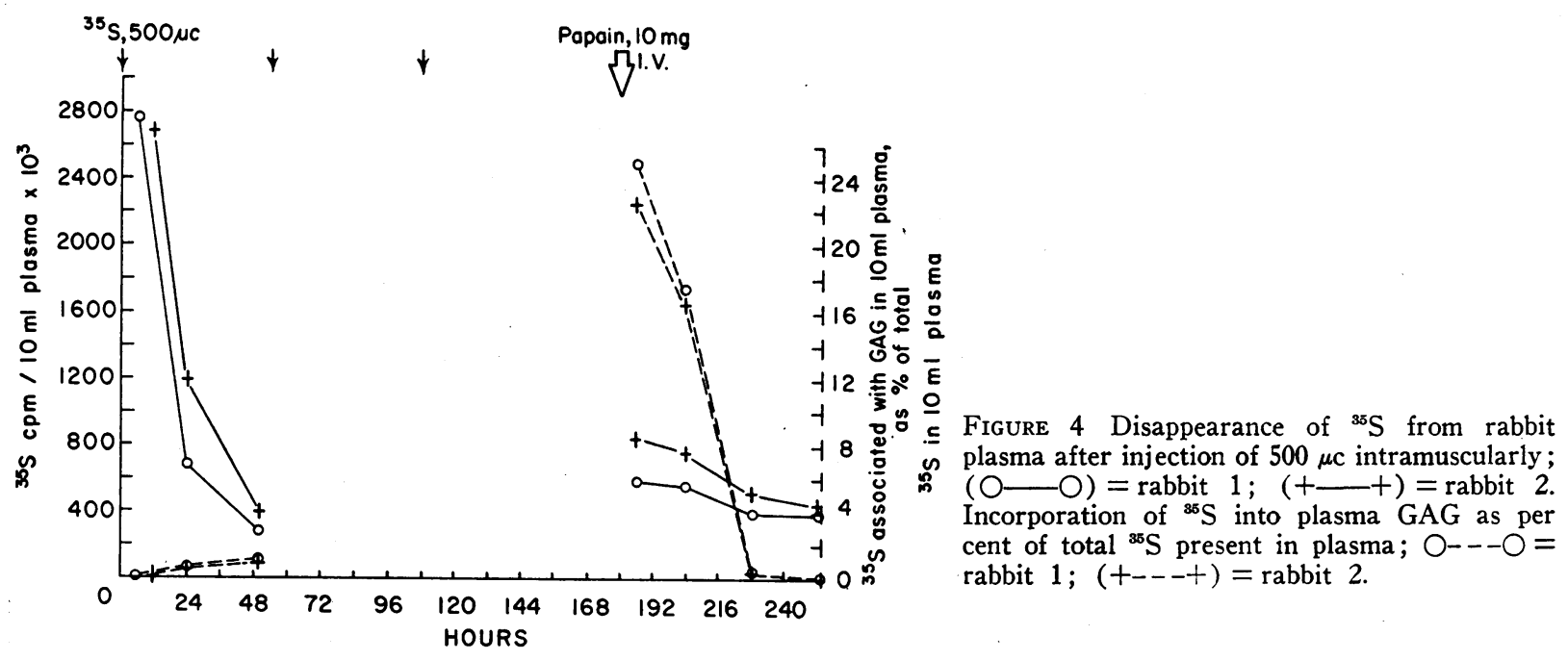

latter are eluted at $\mathrm{NaCl}$ molarities lower than those required for the elution of the "free" GAG.

The analytical data of the "free" and "bound" GAG, before fractionation, after fractionation, and before and after treatment with testicular hyaluronidase are presented in Tables IV and V. The results of the metabolic studies on rabbits may be summarized as follows: 6,12 , and $24 \mathrm{hr}$ after the first injection of sulfate- ${ }^{35} \mathrm{~S}$ into young rabbits (Table VI), the "free" and "bound" plasma GAG show approximately the same specific activity. $50 \mathrm{hr}$ after the injection, however, the specific activity of the "free" GAG increases sharply, whereas that of the "bound" continues to decline. After repetitive injections of sulfate ${ }^{35} \mathrm{~S}$, depletion of tissue GAG with papain is followed by a sharp rise in the level of plasma GAG (the "bound" being more affected than the "free") and by a rapid decrease in the specific activity of both "free" and "bound" plasma GAG. Similar experiments performed in more mature animals produced essentially the same results, with the exception that the specific activity of the "free" GAG did not increase $50 \mathrm{hr}$ after the ${ }^{25}$ S-labeled pulse-dose (Table VII).

TABLE IV

Fractionation on Dowex $1 \times 2$

\begin{tabular}{|c|c|c|c|c|c|c|}
\hline & \multirow{2}{*}{$\begin{array}{l}\text { Hexuronic } \\
\text { acid } \\
\text { (borate) }\end{array}$} & \multirow[b]{2}{*}{ Glucosamine } & \multirow[b]{2}{*}{ Galactosamine } & \multirow{2}{*}{$\begin{array}{c}\begin{array}{c}\text { Galactos- } \\
\text { amine }\end{array} \\
\begin{array}{c}\text { Gluco- } \\
\text { samine }\end{array}\end{array}$} & \multirow[b]{2}{*}{ Sulfur } & \multirow[b]{2}{*}{$\begin{array}{c}\text { Galactose } \\
\text { (anthrone) }\end{array}$} \\
\hline & & & & & & \\
\hline Before fractionation & $0.87(15.3)$ & $0.23(4.1)$ & $0.76(13.4)$ & 3.27 & $0.88(2.7)$ & $0.37(6.1)$ \\
\hline Dowex $1 \times 2$ fractions $0.4,0.6 \mathrm{M} \mathrm{NaCl}$ & 0.27 & 0.45 & 0.54 & 1.2 & & \\
\hline $0.8 \mathrm{M}$ & 0.58 & 0.37 & 0.62 & 1.67 & 1.45 & \\
\hline $1.0 \mathrm{M}$ & 0.63 & 0.32 & 0.67 & 2.06 & 0.91 & \\
\hline $1.2 \mathrm{M}$ & 0.98 & 0.16 & 0.83 & 5.08 & 1.28 & \\
\hline $1.4 \mathrm{M}$ & 1.02 & 0.07 & 0.92 & 12.60 & 1.31 & \\
\hline $1.6 \mathrm{M}$ & 1.04 & 0.16 & 0.83 & 5.17 & 1.08 & \\
\hline \multicolumn{7}{|l|}{ After hyaluronidase treatment: } \\
\hline Dowex $1 \times 2$ fractions $0.2,0.4$ м NaCl & 0.65 & 0.31 & 0.68 & 1.92 & & \\
\hline $0.6 \mathrm{M}$ & 0.64 & 0.23 & 0.76 & 3.30 & & \\
\hline $0.8 \mathrm{M}$ & 0.97 & 0.12 & 0.87 & 6.80 & & \\
\hline $1.0 \mathrm{M}$ & 0.94 & 0.19 & 0.80 & 4.00 & & \\
\hline $1.2 \mathrm{M}$ & 0.58 & 0.39 & 0.60 & 1.50 & & 1.70 \\
\hline $1.4,1.6,1.8 \mathrm{M}$ & 0.30 & 0.68 & 0.31 & 0.46 & & 0.95 \\
\hline
\end{tabular}

* Values are molar or atomic ratio per mole of total hexosamine. Figures in parentheses are per cent values by weight. $\ddagger$ Per cent of total material applied to column, as hexuronic acid.

$\S$ Pink rather than violet color appeared with naphthoresorcinol reaction. 
Fig. 4 illustrates the amount of radioactivity incorporated into plasma GAG (free plus bound) as per cent of the total amount of radioactivity present in plasma at the time of the bleeding. After the pulse-dose of sulfate- ${ }^{25} \mathrm{~S}$, the amount of radioactivity present in rabbit plasma decreases precipitously, while the amount of radioactivity incorporated into GAG increases slowly, to reach a maximum value of $1 \%, 50 \mathrm{hr}$ after the isotope injection. After additional injections of isotope, mobilization of tissue GAG by i.v. papain produces the appearance in the circulation of considerable amounts of radioactivity, $23 \%$ of the total being represented by ${ }^{35} \mathrm{~S}$-labeled GAG. The percentage of radioactivity bound to GAG decreases rapidly, to approach zero values $42 \mathrm{hr}$ after papain injection, as a probable reflection of a rapid rate of GAG excretion and new GAG synthesis from nonlabeled precursors.

\section{DISCUSSION}

The average values of total GAG for normal adults are in good agreement with those reported previously by other authors $(2,4,6)$. In view of the close agreement between duplicate measurements, the great variability found when repetitive analyses were performed on the same subject on different days should not be considered as due to limitations of the proposed technique, but rather as a possible indication that plasma GAG reflect fairly active metabolic processes taking place at the tissue level.
Our data indicate that significant quantitative differences exist between plasma GAG of normal adults and children $(P<0.05)$, but not between normal males and females, either adults or children. The plasma GAG of male children affected by mucopolysaccharidosis type I are significantly higher than those of normal male children $(P<0.01)$ and those of affected female children $(P<0.05)$.

The results of the recovery tests indicate that in the method described, ECTEOLA readily displaces albumin and papain that may be electrostatically bound to chondroitin sulfate and forms electrostatic bonds of its own with the polyanions. However, a fraction of plasma GAG cannot be retained on ECTEOLA before proteolytic digestion, and it is likely that this fraction is "bound" to protein through bonds other than electrostatic. Evidence provided by previous authors $(2,5,6,22)$ seems to indicate that at least a part of plasma GAG may be covalently linked to proteins. The possibility that the "bound" GAG may be linked to plasma proteins by a larger number of electrostatic bonds does not seem to be supported by the results of the fractionation on Dowex $1 \times 2$ columns, nor by the analytical and infrared data. In fact, on fractionation of "free" and "bound" GAG on Dowex columns (before hyaluronidase treatment, Figs. 2 and 3), the latter are eluted at $\mathrm{NaCl}$ molarities lower than those required for elution of the "free" GAG, and this reflects either a lower charge density or a smaller molecular weight (23). That a lower charge density is the

of "Free" Plasma GAG*

\begin{tabular}{|c|c|c|c|c|c|c|}
\hline \multirow[b]{2}{*}{$\begin{array}{l}\text { 2-Deoxy- } \\
\text { 2-sulfoamino- } \\
\text { hexose }\end{array}$} & \multirow[b]{2}{*}{$\begin{array}{l}\text { 2-Deoxy- } \\
\text { 2-amino- } \\
\text { hexose }\end{array}$} & \multicolumn{2}{|c|}{ Ratio OD:OD } & \multicolumn{2}{|c|}{ Intrared absorbancy, $\mathrm{cm}^{-1}$} & \multirow[b]{2}{*}{ Per cent $t$} \\
\hline & & $\begin{array}{c}\text { Borate: } \\
\text { Carbazole }\end{array}$ & $\begin{array}{l}\text { Carbazole: } \\
\text { Naphtho- } \\
\text { resorcinol }\end{array}$ & $\begin{array}{c}860 ; 920 \\
\left(4-\mathrm{SO}_{4}\right)\end{array}$ & $\begin{array}{c}775 ; 820 ; 992 \\
\left(6-\mathrm{SO}_{4}\right)\end{array}$ & \\
\hline & & 2.0 & 5.6 & $+++;++$ & & \\
\hline & & $\begin{array}{l}2.0 \\
2.0 \\
2.2\end{array}$ & $\begin{array}{l}5.2 \\
5.2 \\
3.3 \S\end{array}$ & $\begin{array}{l}++;+ \\
++; \\
++;+ \\
+++;+ \\
+++;++ \\
+++i++\end{array}$ & $\begin{array}{l}+;+ \\
+;++ \\
+;++ \\
+; \\
+;\end{array}$ & $\begin{array}{r}8.1 \\
7.0 \\
6.3 \\
12.3 \\
39.0 \\
20.3\end{array}$ \\
\hline $\begin{array}{l}\text { Neg } \\
0.01 \\
\text { Neg }\end{array}$ & $\begin{array}{l}\text { Neg } \\
0.007 \\
\text { Neg }\end{array}$ & 2.0 & 7.8 & $\begin{array}{l}++i+ \\
+++i++ \\
+++i++ \\
+++;++ \\
++; \\
++;\end{array}$ & $\begin{array}{l}+;+ \\
++;+\end{array}$ & $\begin{array}{r}9.0 \\
30.8 \\
38.0 \\
14.2 \\
4.0 \\
1.5\end{array}$ \\
\hline
\end{tabular}




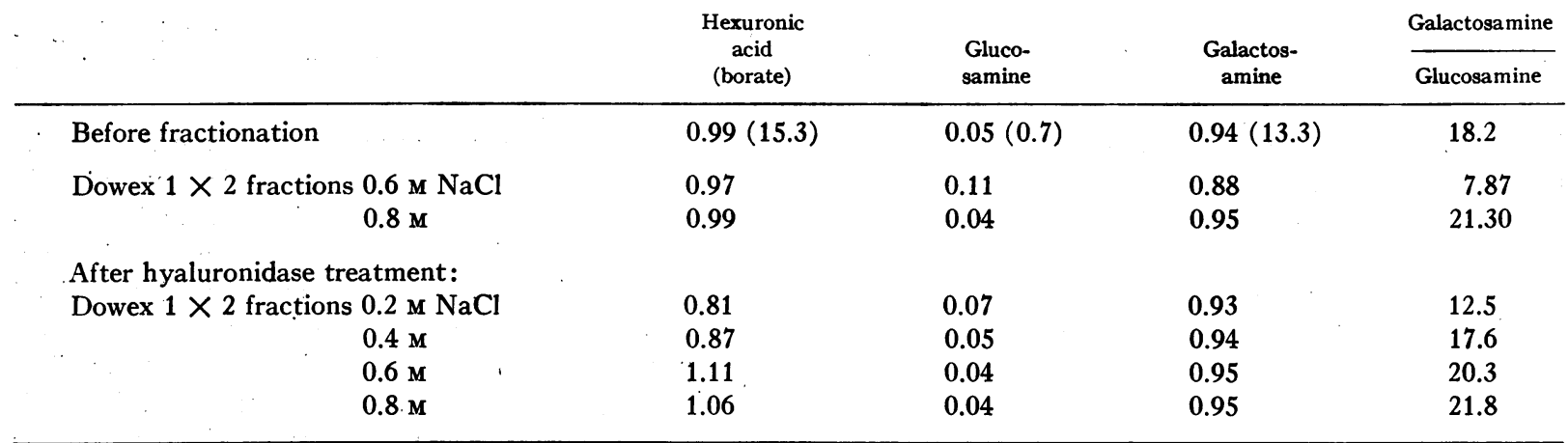

* Values are molar or atomic ratio per mole of total hexosamine. Figures in parentheses are per cent values by weight.

$\ddagger$ Per cent of total material applied to column, as hexuronic acid.

determining factor is demonstrated by the sulfur analyses (Tables IV and V) and by the infrared data which show a lower absorbance in the $\mathrm{SO}_{4}=$ region $\left(1230 \mathrm{~cm}^{-1}\right)$ for the "bound" GAG. Thus, the number of electrostatic bonds with plasma proteins should be less for the "bound" than for the "free" GAG. If it is assumed that the "bound" GAG are covalently linked to protein, the source of this protein-GAG complex and its relationship to the "free" GAG remain to be considered.

The incorporation of sulfate- ${ }^{85} \mathrm{~S}$ into GAG may represent either sulfation of an already existing acceptor or an event during the "de novo" synthesis of GAG (24). The labeling of rabbit plasma GAG obtained 6 , 12 , and $24 \mathrm{hr}$ after a single dose of sulfate $-{ }^{\infty} \mathrm{S}$ probably

TABLE VI

Labeling of Rabbit Plasma GAG with Sulfate- ${ }^{35} \mathrm{~S}$, before and after Intravenous Injection of $10 \mathrm{mg}$ Crude Papain (Young Rabbits)

\begin{tabular}{|c|c|c|c|c|c|c|c|c|c|}
\hline \multirow[b]{3}{*}{ Time } & \multirow[b]{3}{*}{ Treatment } & \multicolumn{4}{|c|}{ Rabbit $1(1.36 \mathrm{~kg})$} & \multicolumn{4}{|c|}{ Rabbit $2(1.36 \mathrm{~kg})$} \\
\hline & & \multicolumn{2}{|c|}{ Free } & \multicolumn{2}{|c|}{ Bound } & \multicolumn{2}{|c|}{ Free } & \multicolumn{2}{|c|}{ Bound } \\
\hline & & Amt* & SA & Amt* & SA & Amt* & SA & Amt* & SAt \\
\hline \multicolumn{10}{|l|}{$h r$} \\
\hline $\mathbf{0}$ & $\begin{array}{c}\text { Sulfate- }{ }^{-85} \mathrm{~S} \\
500 \mu c\end{array}$ & & & & & & & & \\
\hline 6 & & 12.3 & 99.5 & 38.2 & 98.5 & & & & \\
\hline 12 & & & & & & 11.7 & 141.0 & 34.1 & 120.0 \\
\hline 24 & & 9.3 & 91.2 & 34.5 & 97.0 & 27.2 & 91.7 & 34.7 & 103.0 \\
\hline 50 & & 8.8 & 141.0 & 32.8 & 63.0 & 14.4 & 126.0 & 45.9 & 34.0 \\
\hline 54 & $\begin{array}{c}\text { Sulfate- }{ }^{-85} S \\
500 \mu c\end{array}$ & & & & & & & & \\
\hline 108 & $\begin{array}{c}\text { Sulfate- }{ }^{-55} S \\
500 \mu c\end{array}$ & & & & & & & & \\
\hline 180 & $\begin{array}{c}\text { Crude papain } \\
\text { i.v. } \\
10 \mathrm{mg}\end{array}$ & & & & & & & & \\
\hline 186 & & 250.4 & 86.5 & 1380.0 & 92.7 & 256.8 & 101.0 & 1660.0 & 100.0 \\
\hline 204 & & 209.5 & 71.0 & 983.0 & 85.0 & 261.2 & 81.4 & 1810.0 & 57.4 \\
\hline 228 & & 24.0 & 3.7 & 38.9 & 1.5 & 14.8 & 12.0 & 37.0 & 1.4 \\
\hline 252 & & 24.5 & 1.9 & 36.5 & 1.0 & 15.0 & 4.5 & 30.3 & 0.77 \\
\hline
\end{tabular}

* $\mu \mathrm{g}$ Hexuronic acid/10 ml plasma.

$\ddagger \mathrm{cpm} / \mu \mathrm{g}$ Hexuronic acid. 


\begin{tabular}{|c|c|c|c|c|c|c|c|c|}
\hline \multirow[b]{2}{*}{ Sulfur } & \multirow[b]{2}{*}{$\begin{array}{c}\text { Galactose } \\
\text { (anthrone) }\end{array}$} & \multirow[b]{2}{*}{$\begin{array}{l}\text { 2-Deoxy- } \\
\text { 2-sulfoamino } \\
\text { hexose }\end{array}$} & \multirow[b]{2}{*}{$\begin{array}{c}\text { 2-Deoxy- } \\
\text { 2-amino } \\
\text { hexose }\end{array}$} & \multicolumn{2}{|c|}{ Ratio OD:OD } & \multicolumn{2}{|c|}{ Infrared absorbancy $\mathrm{cm}^{-1}$} & \multirow[b]{2}{*}{ Per cent } \\
\hline & & & & $\begin{array}{c}\text { Borate: } \\
\text { Car- } \\
\text { bazole }\end{array}$ & $\begin{array}{c}\text { Car- } \\
\text { bazole: } \\
\text { Naphtho- } \\
\text { resorcinol }\end{array}$ & $\begin{array}{c}860 ; 920 \\
\left(4-\mathrm{SO}_{4}\right)\end{array}$ & $\begin{array}{c}775 ; 820 ; \\
992 \\
\left(6-\mathrm{SO}_{4}\right)\end{array}$ & \\
\hline $0.48(1.16)$ & $0.20(2.9)$ & & & 2.02 & 6.6 & $++;+$ & & \\
\hline $\begin{array}{l}0.59 \\
0.53\end{array}$ & & Neg & Neg & $\begin{array}{l}2.00 \\
2.04\end{array}$ & 8.4 & $\begin{array}{l}++;+ \\
++;+\end{array}$ & & $\begin{array}{l}32.2 \\
63.8\end{array}$ \\
\hline & & & & 2.04 & 5.7 & $\begin{array}{l}++; \\
++; \\
++;+ \\
+++;++\end{array}$ & & $\begin{array}{l}10.8 \\
45.6 \\
33.9 \\
10.5\end{array}$ \\
\hline
\end{tabular}

represents sulfation of polymers that have already left the cellular environment and are in the process of being either excreted or metabolized. In younger rabbits, 50 $\mathrm{hr}$ after the single injection of sulfate- ${ }^{\mathrm{s}} \mathrm{S}$ the specific activity of the "free" GAG increases sharply, whereas that of the "bound" continues to decline. These data indicate that GAG that were synthesized in the peripheral tissues in the presence of a high level of sulfate ${ }^{-55} \mathrm{~S}$ begin to appear in the blood at this time.
Since the specific activity of the "bound" GAG does not increase, one must conclude that at the tissue level the "free" have a faster turnover and are released into the blood stream at a faster rate than the "bound." The limitation of this phenomenon to very young rabbits is in line with the views and results of various authors related to the role of GAG-protein complexes in the process of calcification. The experimental results of Weinstein, Sachs, and Schubert (25) indicate that di-

TABLE VII

Labeling of Rabbit Plasma GAG with Sulfate-35S, before and after Intravenous Injection of $10 \mathrm{mg}$ Crude Papain (Older Rabbits)

\begin{tabular}{|c|c|c|c|c|c|c|c|c|c|c|c|}
\hline \multirow[b]{3}{*}{ Time } & \multirow[b]{3}{*}{.$^{2}$} & \multirow[b]{3}{*}{ Treatment } & & \multicolumn{4}{|c|}{ Rabbit $3(1.7 \mathrm{~kg})$} & \multicolumn{4}{|c|}{ Rabbit $4(2.1 \mathrm{~kg})$} \\
\hline & & & & \multicolumn{2}{|c|}{ Free } & \multicolumn{2}{|c|}{ Bound } & \multicolumn{2}{|c|}{ Free } & \multicolumn{2}{|c|}{ Bound } \\
\hline & & & & Amt* & SAt & $\mathrm{Amt}^{*}$ & SAt & $\mathrm{Amt}^{*}$ & SAt & Amt* & SAt \\
\hline \multicolumn{12}{|l|}{$h r$} \\
\hline 0 & & $\begin{array}{l}\text { Sulfate- }{ }^{-35} \mathrm{~S} \\
\quad 250 \mu c\end{array}$ & & & & & & & & & \\
\hline 6 & & & & 11.6 & 128.0 & 35.5 & 128.0 & & & & \\
\hline 12 & & & & & & & & 8.6 & 48.0 & 32.3 & 52.0 \\
\hline 24 & & & & 23.0 & 89.0 & 30.5 & 96.0 & 7.0 & 44.0 & 28.0 & 49.0 \\
\hline 50 & & & & 7.1 & 64.0 & 31.0 & 61.0 & 9.4 & 26.0 & 31.5 & 15.0 \\
\hline 54 & & $\begin{array}{c}\text { Sulfate- }{ }^{-35} \mathrm{~S} \\
250 \mu c\end{array}$ & & & & & & & & & \\
\hline 108 & & $\begin{array}{c}\text { Sulfate-35S } \\
250 \mu c\end{array}$ & & & & & & & & & \\
\hline 180 & & $\begin{array}{l}\text { Crude papain, } \\
\text { i.v. } \\
10 \mathrm{mg}\end{array}$ & ' & & - & & & & & & \\
\hline 186 & & & & 158.4 & 98.0 & 688.0 & 88.0 & 183.7 & 74.0 & 965.0 & 73.0 \\
\hline 204 & & ' & & 26.0 & 97.0 & 45.0 & 59.0 & 96 & 57.0 & 652.0 & 52.0 \\
\hline
\end{tabular}

* $\mu \mathrm{g} \cdot$ Hexuronic acid/10 $\mathrm{ml}$ plasma.

$\ddagger \mathrm{cpm} / \mu \mathrm{g}$ Hexuronic acid. 
gestion of the protein moiety of protein-GAG complexes allows the precipitation of calcium phosphate from metastable solutions. On the other hand, Gerber and Schubert have also pointed out that protein-free GAG are immediately extruded from cartilage because of the "excluded volume" effect caused by the presence therein of proteinGAG complexes (26). The experimental results of Hirschman and Dziewiatkowski (27) indicate that the protein moiety of the protein-GAG complexes is indeed decreased or modified in calcifying tissues through the action of proteases (28). One would expect that these processes, and the release of "free" GAG into circulation, would be more evident in very young animals who undergo an almost constant process of remodeling and calcification.

In view of the well-known effects of papain on cartilage and connective tissue $(21,29)$, our data indicate that both "free" and "bound" GAG are present in peripheral tissues; since the latter are more abundant, they are mobilized to a greater extent and constitute a larger aliquot of the plasma GAG. The fact that the specific activities of the "free" and "bound" GAG decline almost at the same rate after papain injection indicates that both pools are being diluted equally by the newly synthesized, nonradioactive tissue GAG. It may be concluded that the metabolic events transforming part of the "bound" GAG into "free" GAG must be fairly rapid, to the extent that the two pools are practically in equilibrium. One may speculate that both the "free" and "bound" GAG derive from tissue protein-GAG complexes and represent the products of different tissue metabolic activities, the former being mainly the product of proteolytic digestion (28) and the latter of depolymerization and partial desulfation. These two pools possess more than a superficial resemblance to those recently proposed by Fratantoni, Hall, and Neufeld (30) on the basis of studies on cultures of normal and abnormal fibroblasts.

Once in the blood stream, the "free" GAG could establish electrostatic linkages with plasma proteins, while the "bound" would remain covalently linked to fragments of tissue proteins that have not been completely digested by tissue proteases. Some observations made in our laboratory confirm the latter point. If an antiserum to bovine protein-GAG complex is absorbed with polymerized, whole bovine serum (31), its ability to agglutinate red cells coated with the bovine protein-GAG complex is completely lost. This is compatible with the presence in bovine serum of a component having the immunological properties of the bovine protein-GAG complex. It is of interest, in this connection, that the presence of collagen-like components, immunologically related to human skin collagen, have been found recently in human serum (32).

The analytical data indicate that the "bound" GAG consist essentially of chondroitin-4-sulfate with low sulfate content. The preponderant presence of galactosamine in every fraction, the infrared pattern, and the effect of testicular hyaluronidase support this conclusion (Fig. 2, Table V). Despite the extensive purification, the "free" GAG still seem to be contaminated by a glucosamine-containing material, which is eluted from Dowex $1 \times 2$ columns with $0.4-0.8 \mathrm{M} \mathrm{NaCl}$. The presence in the latter eluate of small amounts of 2-deoxy-2sulfoaminohexose and 2-deoxy-2-aminohexose indicates that some heparan sulfate may be present. The presence of glucosamine and galactose in fractions 1.2-1.8 $\mathrm{M}$ $\mathrm{NaCl}$ after treatment with testicular hyaluronidase is strongly suggestive of the presence of keratan sulfate. The infrared pattern of this material demonstrates the presence of sulfate esters in position 6 and the absence of carboxylic groups, thus confirming the analytical data. The larger amount of the "free" GAG is, however, represented by galactosamine-containing, fully sulfated compounds that are eluted from Dowex $1 \times 2$ columns and are affected by testicular hyaluronidase like a standard of skeletal chondroitin sulfate. The infrared patterns indicate a great preponderance of ester sulfate in position 4 and only a few in position 6 (Fig. 3 , Table IV). The possible presence of dermatan sulfate in the two pools seems to be excluded by the values of the ratios of borate : carbazole and carbazole : naphthoresorcinol $(15,33)$.

These results are in good agreement with those obtained by previous authors (3-6) and confirm that chondroitin-4-sulfate is the main glycosaminoglycan of normal human plasma. The reported presence of components resistant to the action of testicular hyaluronidase (6) may be due to the small amounts of heparan sulfate and keratan sulfate demonstrated, or to the possible presence of excessive amounts of protein in some crude preparations. Certainly, the latter factor, added to variations in charge density of the different GAG fractions, must have contributed to the electrophoretic and chromatographic heterogeneity of plasma GAG which has been previously reported (7).

The demonstration that plasma GAG consist of two pools, quite similar in structure but reflecting different metabolic events, may be of importance in the clinical investigation of diseases involving an abnormal turnover of glycosaminoglycans and may very well complement studies performed on "in vitro" systems.

\section{ACKNOWLEDGMENTS}

We wish to thank Mrs. Nancy Wilson for excellent technical assistance.

This project was carried out while one of the authors, Dr. Di Ferrante, was an Established Investigator of the American Heart Association.

This investigation was supported by grant AM 10811 from the U. S. Public Health Service and grant Q-236 from 
the Robert A. Welch Foundation; and by grants-in-aid from the American Heart Association (66-639) and the Texas and Houston Heart Associations. Statistical evaluation of the data was performed by the Common Research Computer Facility, supported by U. S. Public Health Service grant FR 00254.

\section{REFERENCES}

1. Balazs, E. A., and R. W. Jeanloz. 1965. The Amino Sugars. Academic Press Inc., New York.

2. Badin, J., M. Schubert, and M. Vouras. 1955. Plasma polysaccharide fractions containing uronic acid, in normal subjects and in patients with rheumatoid arthritis. J. Clin. Invest. 34: 1317.

3. Bassiouni, M. 1955. Studies of the acid polysaccharides of the white cells in rheumatic and other diseases showing its similarity to the acid polysaccharide of amyloid. Ann. Rheum. Dis. 14: 288.

4. Bollet, A. J., M. W. Seraydarian, and W. F. Simpson. 1957. Acid mucopolysaccharides in normal serum. $J$. Clin. Invest. $36: 1328$.

5. Kerby, G. P. 1958. The distribution of acid mucopolysaccharides in Cohn fractions of human plasma proteins. J. Clin. Invest. $37: 678$.

6. Schiller, S. 1958. The isolation of chondroitinsulfuric acid from normal human plasma. Biochim. Biophys. Acta. 28: 413 .

7. Friman, C., and R. Brunish. 1966. A zone electrophoretic study of acid mucopolysaccharides (AMPS) in normal human serum. Proc. Soc. Exp. Biol. Med. 122: 599.

8. Wessler, E. 1967. Determination of acidic glycosaminoglycans (mucopolysaccharides) in urine by an ion exchange method. Application to "collagenoses," gargoylism, the nail-patella syndrome and Farber's disease. Clin. Chim. Acta. 16: 235.

9. Di Ferrante, N. 1967. The measurement of urinary mucopolysaccharides. Anal. Biochem. 21: 98.

10. McKusick, V. A., D. Kaplan, D. Wise, W. B. Hanley, S. B. Suddarth, M. E. Sevick, and A. E. Maumanee. 1965. The genetic mucopolysaccharidoses. Medicine. 44: 445.

11. Berman, E. R. 1966. Separation of connective tissue mucopolysaccharide-protein complexes from unrelated proteins. Nature. 211 : 640 .

12. Muir, H. 1958. The nature of the link between protein and carbohydrate of a chondroitin sulfate complex from hyaline cartilage. Biochem. J. 69: 195.

13. Schiller, S., G. A. Slover, and A. Dorfman. 1961. A method for the separation of acid mucopolysaccharides: its application to the isolation of heparin from the skin of rats. J. Biol. Chem. 236: 983.

14. Dische, Z. 1947. A new specific color reaction of hexuronic acids. J. Biol. Chem. 167: 189.

15. Bitter, T., and H. M. Muir. 1962. A modified uronic acid carbazole reaction. Anal. Biochem. 4: 330.
16. Pelzer, H., and W. Staib. 1957. Steroidkonjugate. I. Hochspannungs-papierelektrophorese von 17-ketosteroidkonjugaten. Clin. Chim. Acta. 2: 407.

17. Dische, Z., and E. Borenfreund. 1950. A spectrophotometric method for the microdetermination of hexosamines. J. Biol. Chem. 184: 517.

18. Lagunoff, D., and G. Warren. 1962. Determination of 2-deoxy-2-sulfoaminohexose content of mucopolysaccharides. Arch. Biochem. Biophys. 99: 396.

19. Scott, J. A.. Jr., and E. H. Melvin. 1953. Determination of dextran with anthrone. Anal. Chem. 25: 1656.

20. Calatroni, A., and N. Di Ferrante. 1968. Oversulfated dermatan sulfate extracted from Hurler spleen. Anal. Biochem. In press.

21. Thomas, L. 1956. Reversible collapse of rabbit ears after intravenous papain and prevention of recovery by cortisone. J. Exp. Med. $104: 245$.

22. Dziewiatkowski, D. D., and N. Di Ferrante. 1957. Association of sulfate-S ${ }^{35}$ with serum proteins in the rat. $J$. Biol. Chem. 227 : 347.

23. Cleland, R. L., M. C. Cleland, J. J. Lipsky, and V. E. Lyn. 1967. Ionic polysaccharides. I. Adsorption and fractionation of polyelectrolytes on (Diethylamino) ethyl cellulose. J. Amer. Chem. Soc. 90: 3141.

24. Meezan, E., and E. A. Davidson. 1967. Mucopolysaccharide sulfation in chick embryo cartilage. J. Biol. Chem. 242: 4956

25. Weinstein, H., C. R. Sachs, and M. Schubert. 1963. Proteinpolysaccharide in connective tissue: inhibition of phase separation. Science. 142: 1073.

26. Gerber, B. R., and M. Schubert. 1964. The exclusion of large solutes by cartilage proteinpolysaccharide. Biopolymers. 2 : 259 .

27. Hirschman, A., and D. D. Dziewiatkowski. 1966. Proteinpolysaccharide loss during endochondral ossification: immunochemical evidence. Science. 154: 393.

28. Tourtellotte, C. D., R. D. Campo, and D. D. Dziewiatkowski. 1963. Degradation of chondromucoprotein by an enzyme extracted from cartilage. Fed. Proc. 22: 413.

29. Thomas, L., R. T. McCluskey, J. L. Potter and G. Weissmann. 1960. Comparison of the effects of papain and vitamin $A$ on cartilage. I. The effects on rabbits. J. Exp. Med. $111: 705$.

30. Fratantoni, J. C., C. W. Hall, and E. F. Neufeld. 1968. The defect in Hurler's and Hunter's syndromes: faulty degradation of mucopolysaccharides. Proc. Nat. Acad. Sci. U.S.A. 60: 699.

31. Avrameas, S., and T. Ternynck. 1967. Biologically active water-insoluble protein polymers. I. Their use for isolation of antigens and antibodies. J. Biol. Chem. 242: 1651.

32. Oh, S. I., B. J. Neff, and W. D. Block. 1968. Soluble collagen in human serum. Clin. Chim. Acta. 21: 1 .

33. Teller, W. M., J. W. Rosevear, and E. C. Burke. 1961. Identification of heterozygous carriers of gargoylism. Proc. Soc. Exp. Biol. Med. 108: 276. 